\title{
Can HRM Alleviate the Negative Effects of the Resource Curse on Firms? Evidence from Brunei
}

\begin{abstract}
Purpose: The resource curse literature suggests that firms operating in non-oil and gas industries in petrostates face considerable challenges in securing competitiveness and sustaining themselves. Based on a firm level survey within a micro-petrostate, Brunei, this study explores the relationship between specific HR policies and practices and organisational performance, analysing, comparing and contrasting oil and gas with non-oil and gas sectors, and draws out the comparative lessons for understanding the potential and performance consequences of HR interventions in resource centred national economies.
\end{abstract}

Design/methodology/approach: Data for this study was generated from a primary survey administered amongst the HR Directors in companies operating in all sectors in Brunei. A statistically representative sample size of 214 was selected.

Findings: We confirmed that firms in the oil and gas sector indeed performed better than other sectors. However, we found that the negative effects associated with operating outside of oil and gas could be mitigated through strategic choices: the strategic involvement of HR directors in the affairs of the company reduced employee turnover and added positively to financial returns across sectors.

Practical implications: Developing and enhancing the role of people management is still very much easier than bringing about structural institutional reforms: the study confirms that at least part of the solution to contextual difficulties lies within, and that the firm level consequences of the resource curse can be ameliorated through strategic choice.

Originality/value: The nature of the present investigation is one of few studies conducted in South East Asia in general and in the context of Brunei in particular. It also contributes to our understanding whether HR interventions can ameliorate the challenges of operating in a nonresource sector in a resource rich country.

Keywords: Human resources; employee turnover; perceived financial performance; resource curse theory; oil and gas sector. 


\section{Introduction}

As the literature on the 'resource curse' alerts us, firms operating in national economies with significant oil and gas industries face serious challenges in securing competitiveness. This is owing to the tendency for the oil and gas sector to crowd out investment in physical and human capital in other areas, associated governance problems, a tendency for policy makers to look to oil and gas to resolve developmental problems rather than promoting more broadly based institution building, and currency over-valuation and volatility (Collier 2010; Ross 2012). In many petrostates, the oil and gas sector is closely controlled and regulated, whilst non-resource industries are neglected (Auty, 1993). In such challenging circumstances, it can be argued that the human dimensions of organizational competitiveness are vested with particular importance. Based on the case of a micro petrostate, Brunei, this paper looks at the extent to which HR practices may help mitigate negative sectoral effects, comparing and contrasting the case of firms operating within the oil and gas sector with those operating in other sectors, and draws out the comparative lessons for understanding the potential and performance consequences of HR interventions in resource centred national economies.

In exploring the link between HR practices and performance, the impact of strategic HR involvement and devolvement in organisations has received increasing attention (see, for example, Pfeffer, 1998; Budhwar, 2000; Paauwe, 2009; Guest, 2011; Sheehan, 2012; Singh et al., 2012b; Darwish et al., 2015). The integration of Human Resource Management in the formulation of business strategy is referred to as strategic HR involvement (SHRI); HR devolvement (SHRD), on the other hand, can be defined as the devolution of key HR practices to Line Managers, and away from personnel specialists (Brewster \&Larsen, 1992; Darwish and Singh, 2013). It has been argued that the integration of HR practices and policies within business and corporate strategy may enhance the overall organisational 
performance (OP), as might HR devolution, and ameliorate any challenges posed by context (see Cunningham and Hyman, 1999; Budhwar, 2000; Andersen et al., 2007; Karami et al., 2008; Sheehan, 2012). However, a number of studies on this have been carried out in the West; hence, this article is an attempt to fill this lacuna through focusing on the case of an emerging market petrostate.

More specifically, we explore the impact of specific SHRI and SHRD on employee turnover, and the managerial perceptions of financial performance across all industries in the petrostate of Brunei, and whether such interventions can ameliorate the challenges of operating in a non-resource sector in a resource rich country. The country is a relatively developed and stable Southeast Asian country with rich natural source endowments. It could be further claimed that firms operating in comparable markets, as well as in commodity-driven economies, could learn valued lessons from the Bruneian context, especially in terms of differences be, and whether the challenges faced in non-oil and gas sectors in such contexts are insurmountable.

\section{The Resource Curse and Firm Competitiveness}

The resource curse literature suggests that resource rich countries tend to be characterized by inferior and more volatile macro-economic performance when compared to those with less mineral riches (Anderson and Ross 2010; Auty 1993; Alexeev and Conrad 2009; Bhattacharya and Hodler 2010). This is due to the tendency for currencies to be over-valued, making other industries less competitive, investors concentrating on the easy returns from minerals and on securing lucrative contracts from royalty enriched governments. The latter in turn, have fewer incentives to promote the deepening of institutions and associated policies aimed at securing broader based economic development, or promote and support 
developmental initiatives that are difficult to sustain without continued financial lifelines, making for volatile and uneven sectoral performance (Collier 2010; Ross 2012). Critics have charged that countries indeed benefit from natural resource windfalls (c.f. Alexeev and Conrad 2009; Haber and Menaldo 2001). However more recent work has pointed to the fact that such studies drew on a particular panel of countries and time period; in the present time of historically high and volatile commodity prices, the challenges faced in promoting broad based development from natural resource booms have become even more intense (Andersen and Ross 2015; Wiens et al 2015). What does this mean for then for the practice of HRM? Firstly, the particularly uneven nature of growth is likely to lead to skills gaps in non-resource sections of the economy (Nuur and Laestadius, 2010). Secondly, lucrative protected job opportunities in the state sector, and from oil and gas firms seeking to secure the goodwill of authorities leads to high staff turnover, and drain talent from other areas of the economy (Mellahi and Wood 2002; Mellahi 2007). Again, given that oil and gas endowments may raise the political stakes (as the possibilities for capturing lucrative rents are enhanced) (Bhattacharya and Hodler 2010), governments of petrostates often seek to expand state employment in order to promote stability; in turn, this may further denude the human resources available to other areas of the economy, and make it harder for employers in the latter to seek to enforce discipline or enhance productivity. Indeed, rather than coping with efforts to intensify work or productivity in other sectors, employees may simply seek to opt out, falling back on generous welfare provisions or more conducive sheltered employment elsewhere. In seeking to cope with such challenges, it could be argued that the relative devolvement of the HR function, allowing managers to flexibly respond to such day to day challenges, and vesting HR with a core strategic importance, allowing for a greater allocation of resources to internal training and skills development, and to promote retention, is critical; however, by the same measure, a lack of resources may make this more difficult, and the 
contextual circumstances may be too daunting for HR interventions to have any effect (c.f. Mellahi 2007).

\section{Context of Research}

Brunei is a fast-growing micro- and petrostate. Like many other countries of a similar status, the country is characterised by a relatively strong presence of foreign multinationals and a large expatriate workforce, both encompassing skilled professionals, and semi-skilled and unskilled labourers. Professional expatriates may experience difficulties in adjusting to local cultural norms, but bring with them new skills, capabilities and insights. In contrast, semiand unskilled migrants - in the case of Brunei, mostly from Indonesia, the Philippines and Malaysia, but also from China and Thailand - tend to be condemned to low wages and lowstatus labour, with poor performance or dissent resulting in rapid dismissal and deportation (Santoso, 2009). In Brunei, the net migration rate is 2.4 migrant(s)/1000 in 2015 (CIA, 2016). There are around 200,000 individuals recognised as part of the labour force - both employed and unemployed. It was found that there was a $68 \%$ labour force participation rate, with almost 55,000 individuals employed in the public sector while just over 91,000 were employed by the private sector. Of those employed, 53.7\% were Brunei citizens whilst $46.3 \%$ were temporary residents. Temporary residents are made up of foreigners working in Brunei and locally-born foreigners who cannot achieve citizenship of the country. It has been stated by the Brunei government that, considering the need for a more diverse economy, there needs to be a larger labour force; however, it is acknowledged that there is a pressing need for migrant workers to facilitate diversification plans as the mainstream Bruneian local labour force has a preference for public sector roles owing to the comfort and stability offered by such work (Tasie, 2009). Meanwhile, local workers benefit from indigenisation legislation, and, in regional terms, have access to a good local vocation training and skills development 
system, owing to good jobs in the public sector, locals have been reluctant to take-up technical and skilled jobs in the private arena (Minnis, 2000). This highly segmented workforce would make the task of the HR Manager-especially in multinationalsparticularly challenging. Again, this segmentation might suggest that the devolvement of the HR function could yield particular benefits; as the segment(s) of workforce they have to manage may vary from Line Manager to Line Manager, this may allow the firm to benefit from more detailed frontline knowledge in regard to the needs and capabilities of particular categories of worker. Similarly, whilst there are dominant ways of managing each of these three very different categories of labour, it is likely that enhanced opportunities for HRM to play a strategic role may make the organisation more responsive to each group's needs, capabilities and potential.

Much like a number of other oil-producing countries, Brunei's economy has experienced both the ups and downs of the global oil market, with a $2.8 \%$ average increase in economic growth experienced in the 2000s, marked by a notable reliance on the production of oil and gas. The economy of Brunei needs to be less dependent on the oil and gas industries; the latter accounted for more than $60 \%$ of GDP and over $90 \%$ of total country's exports (OECD, 2014). Brunei is recognised as the fourth largest producer of oil in the Southeast Asian region. The main export destinations include ASEAN countries, South Korea, Australia, New Zealand, India and Japan. Moreover, in terms of liquefied natural gas exportation, Brunei is known to be the ninth largest exporter, the majority of which is being exported to Japan and South Korea as liquefied natural gas. Due to the country's over reliance on the oil and gas sector, this has somewhat affected the development of the private sector in the country; as a matter of fact, the non-oil-and gas industries have contributed steadily around 20\% to GDP in recent years $(\mathrm{OECD}, 2014)$. As a result of Brunei being reliant on oil and gas industries, it now has a larger government sector, which limited the role and the opportunities offered by 
the private sector. The dominance of the oil and gas industries is further strengthened by the mixture of high labour wages and low productivity; the latter indeed makes much of the private sector internationally uncompetitive (Lawrey, 2010; OECD, 2014).

Again, as noted above, within commodity-centred economies, there is likely to be much variation in practice between the minerals and non-minerals sector. In consideration to such challenges facing the non-primary commodities-based sectors, it could be argued that the human dimension of competiveness is likely to be vested with particular importance in the latter. Hence, we focus on sector, differentiating between oil and gas, and non-oil and -gas.

\section{HR Practice and Performance}

\section{Strategy, HR Involvement and HR Devolvement}

The existing literature on HR involvement and devolvement views the concept as an expression of organisational commitment to managing people strategically (Truss and Gratton, 1994; Darwish and Singh, 2013). If people are an organisation's most valued asset and have to be deployed optimally in order to achieve organisation goals, then, in order to do so, they have to be effectively involved and integrated within the strategic activities of the firm; again, it could be argued that the day-to-day HR issues to Line Managers may free-up the HR department to concentrate on issues of strategy (Cunningham and Hyman, 1999; Budhwar, 2000; Singh et al., 2012a). More closely linking the HR function with the organisation's strategic decision-making process recognises the importance of effective and efficient HRM in obtaining enduring competitive advantage (Budhwar, 2000; Truss et al., 1997). As noted above, HR devolvement, concerns the delegation of HR practices to Line Managers, entrusting them with administering and implementing these tasks as a result of their close proximity to their subordinates, making it easier to manage, control and motivate 
them (Cunningham and Hyman, 1999; Budhwar and Khatri, 2001). The devolution of these tasks to Line Managers helps resolve issues that require intimate insider knowledge, which are sometimes too complicated for top management to handle on an independent basis. It also has been argued that closer ties and communication between Line Managers and the HR Director can help the latter to realise and better understand the problems within different organisational functions, and to enable quicker responses to employee concerns (Sullivan, 2003). It can also free-up the HR function to play a more active role in the organisation's strategic process. Moreover, strategic HR involvement and HR devolvement can both ensure more effective implementation for High Performance Work Systems (HPWSs) within organisations, and without them, HPWS will not be viable. It is held that companies with effective HPWS share and openly communicate information in relation to organisational strategy and goals where employees can understand the important link between HR practices and business strategy; this in turn would increase the perceived relevance of HPWS and further ensure a high level of strategic HR integration (see Lawler, 1992; Becker \& Huselid, 1998; Pfeffer, 1998; Evans and Davis, 2005, Bowen and Ostroff, 2014). On the other hand, empowerment is also an important organisational practice which could further support HPWS in its positive relationship with organisational performance (Pfeffer, 1998; Huang, 2000).

\section{HRM and Organisational Performance (OP)}

There is a wide body of literature on the relationship between HR interventions and performance, albeit with divergent results (see Rogers \& Wright, 1998; Paauwe, 2009; Guest, 1997, 2011). Given the latter, we first of all seek to re-evaluate the nature and strength of any linkage as a starting point for exploring contextual variations. The divergence of results might reflect the extensive debate as to what exactly constitutes OP, reflecting not only variations in national accounting standards, but also how other than short-term share price might reflect 
strong performance and for whom (Rogers and Wright, 1998). However, it may also reflect structural differences national systemic features; as the literature on comparative capitalism alerts us, the optimal combination of rules and firm level practices varies extensively from context to context (Wood et al. 2014). Hence, not only will formal and informal rules encourage firms to adopt specific sets of HR practices, but also in some contexts high value added HR paradigms will work much better than in others (ibid.; Brewster et al. 2007). In other words, the choice, viability and sustainability of specific HR paradigms and associated work systems is closely bound up with contextual circumstances.

HRM researchers have tended to follow on Dyer and Reeves' (1995) classification of the performance outcomes in HR terms (e.g., employee turnover, absenteeism, job satisfaction, commitment), organisational outcomes (e.g., productivity, quality, service, efficiencies, customer satisfaction), and financial and capital market indicators (e.g., profits, sales, return on assets, market share, stock price, and growth). Hence, Paauwe and Boselie (2005) argue there are multiple possible measures of performance, covering the numerous goals of HRM, and the different parties that have been involved either within or outside of the organisation. Largely, the research in this area in particular had been concerned with evaluating the level of strategic HR involvement and HR devolution rather than measuring their direct impacts on performance (see,for example, Budhwar\& Sparrow, 1997; Khatri, 1999; Budhwar, 2000; Andersen et al., 2007; Othman, 2009, Singh et al., 2012a).

The resource curse literature suggests that institutional arrangements are geared towards servicing the minerals sector, the latter sucking talent and investment capital from other areas of the economy (Nuur and Laestadius 2010; Mellahi 2007; Auty 1993). Such powerful backwash effects will mean that strategic HR interventions in firms in the latter area of the 
economy will be very much less effective in reducing employee turnover and in enhancing firm performance.

Hence, we first propose the following two related hypotheses:

H1: There is a negative relationship between strategic HR involvement and HR devolvement, and employee turnover; the greater the involvement and devolvement, the lower the employee turnover rate. However, these effects are concentrated in the oil and gas sector.

H2: There is a positive relationship between strategic HR involvement and HR devolvement, and perceived financial performance. The higher the involvement and devolvement, the higher the perceived financial performance. However, these effects are concentrated in the oil and gas sector.

As noted above, the resource curse literature suggests that in countries with rich mineral resource endowments, other sectors of the economy will battle to compete. In turn, such firms could be more likely to be locked into a basic survival mode, with fewer resources - and will - to devote to strategic HR issues. In other words, even if strategic HRM could ameliorate some of the challenges of operating in non-resource sectors, it may be less likely. The resource curse literature suggests that in-firm interventions are unlikely to ameliorate the negative effects of operating in a resource rich context (Auty, 1993). Hence, we propose the following hypothesis:

H3: There will be significant differences between oil and gas and non-oil and gas sectors in the incidence of strategic HR involvement and HR devolvement. Non-oil and gas sector place less emphasis on SHRI and HRD issues compared to oil and gas sector. 


\section{Methodology}

\section{Data and Sample}

Data for this study was generated from a primary survey administered amongst the HR Directors in companies operating in all sectors in the country of Brunei Darussalam. A count revealed a total of 465 companies in Brunei. A statistically representative sample size of 214 was selected. Postal and face-to-face follow-ups yielded 151 usable replies, amounting to a response rate of $70 \%$. Having such a high response rate is noteworthy and meets the criteria suggested for applied research (Moser and Kalton, 1985). The unit of analysis in the present work is the organisation, and respondents targeted are HR Directors given their experience and knowledge on issues investigated in this study.

\section{Measurement of Variables}

Strategic HR involvement and HR devolvement:

As noted above, HR Directors play a key role in the implementation of strategic HR involvement and HR devolvement in organisations. Hence, we investigate the impacts of these aspects on performance by analysing the role of HR Directors in terms of their involvement in the strategic affairs within the company and in the devolvement of routine HR administrative tasks to Line Managers to free up time and resources for more strategic issues. For the purpose of the present work, we developed measures on these variables based on the existing SHRM literature (see Budhwar\& Sparrow, 1997; Budhwar, 2000; Andersen et al., 2007; Sheehan, 2012; Singh et al, 2012a; Darwish and Singh, 2013).

HR directors were asked four questions on their contribution to the firm by way of their involvement: what was the HR director's contribution to planning and implementation of business and corporate strategies; if they had become more influential in the corporate 
decision making process; the level of their representation in Board meetings; and in overall organisational design. With regard to devolvement, HR directors were asked how well they delegated routine HR functions to line managers to enable them to focus on strategic issues of long-term importance. The replies were measured on Likert scale 1 to 5 (5 being most important). Table 1 shows the items measuring the extent of $\mathrm{HR}$ involvement and devolvement process.

Outcome variable:

Following recommendations in literature (Dyer and Reeves, 1995; Paauwe, 2009), we have taken into account two outcome variables to reflect a better picture of OP, namely employee turnover rate and perceived financial performance. The following sections explain the rationale and measurement underlying these two outcome variables.

Employee turnover: Following the classification provided by Dyer and Reeves (1995), employee turnover is recognised as an important behavioural outcome variable and can reflect OP in terms of HR-related outcomes. It has been argued that an organisation's inability to retain competent and skilled employees can be considered a barrier to their success (Holt, 1993). In the context of HRM-performance research, several works (e.g., Arthur, 1994; Huselid, 1995; Guthrie et al., 2009) consider employee turnover as a vital outcome variable and an essential behavioural indicator of OP. Following most prior work (see, for example, Arthur, 1994; Huselid, 1995; Way, 2002; Darwish et al., 2013), employee turnover rate is measured by the percentage of total employees that voluntarily leave the company each year.

Perceived financial performance: As a significant amount of prior empirical work conducted on the HRM-performance link has employed subjective measures of performance (see, for 
example, Delaney and Huselid, 1996; Wright et al., 1999; Andersen et al, 2007; Chand and Katou, 2007; Macky and Boxall, 2007; Joseph and Dai, 2009; Moideenkutty et al., 2011; Razouk, 2011), we aim to measure the perceived financial performance of the targeted companies. The use of subjective measures is further supported by some empirical work, especially in strategy literature (see, for example, Dess and Robinson, 1984; Geringer and Hebert, 1991; Powell, 1992). Authors such as Dess and Robinson (1984) and Tzafrir (2005) have suggested that the self-reported measures of performance are acceptable, and are found to be as equally reliable as objective measures. Powell (1992), in one of the earliest studies exploring this link conducted on a subset of 52 firms from his studied sample in the US, identified some positive connections between both subjective and objective measures of OP (sales growth and profitability). In addition, a number of authors found that the subjective measures of performance enable managers to factor on the company's objectives when evaluating their performance, and only limited biases are associated with managerial-reported performance data (Wall et al., 2004).

In measuring perceived financial performance, we follow subjective approaches (see, for example, Darwish et al., 2015; Singh et al. 2016). In the present work, perceived financial performance was measured by three items in a Likert scale by a special section in the questionnaire, which directly asked respondents to rate their main financial indicators comparing with their rivals. Items were measured on a Likert scale ranging from 1 'lowest performing' to 10 'highest performing'. The results of exploratory factor analysis indicated that the three items that are recognised as strong measures of this construct are sales revenue, profitability (after tax), and holding market share. As shown in Table 1, the items had individual loadings ranging from 0.870 to 0.952 , thus emphasising highly reliable items to measure perceived financial performance. Notably, the study follows the cross-sectional design adopted by several authors in HRM-performance research (Arthur, 1994; MacDuffie, 
1995; Delaney and Huselid, 1996; Bae and Lawler, 2000; Way, 2002; Wright et al., 2005; Darwish et al., 2015), wherein both predictors and outcome variables are measured on one occasion only.

\section{Methods}

In order to test the hypotheses on sector and strategic HR involvement and HR devolvement and their relation with OP, a number of approaches we first tested the validity (convergent and discriminant) and reliability of variables under consideration as shown in Table 1. The descriptive analysis of data in Table 2 presents means, standard deviation and zero-order correlations for all variables. Multiple regression analysis was used for the modelling of the data. For comparison purposes, Mann-Whitney test was used as this test is a non-parametric equivalent of the independent t-tests.

\section{Convergent and Discriminant Validity}

Convergent validity can be assessed by three main indicators in terms of factor loadings, Average Variance Extracted (AVE), and reliability of the construct (see Hair et al., 2010). Firstly, factor loadings should be .5 or higher in order to be considered meaningful. As recorded in Table 1, the factor loadings of each construct indicators are significant, ranging from 0.671 to 0.952 , emphasising a strong association between constructs and their factors. Secondly, AVE indicates the amount of variance explained by the construct in relation to the variance due to the measurement error. Fornell and Larker (1981) claim that constructs can establish convergent validity if AVE values are at least .50. As recorded in Ta ble 1, AVE values are greater than the threshold value of 0.50 , thus demonstrating adequate convergence of the constructs. Finally, the third indicator that could reflect convergent validity is the reliability of the constructs. The results of the inter-item consistency test, as shown in Table 
1, indicate that the scales satisfy the reliability criterion; the alpha coefficients were sufficient to draw the conclusion of internal consistency ranging from .69 to .90 (Nunnally, 1967). Given the satisfactory results of the aforementioned indicators, the results of factor loadings, AVE and reliability tests provide sufficient confirmation of the convergent validity. Furthermore, we compared the square roots of AVE values with the constructs' correlations, with the results showing that the square roots of the AVE values were higher than any correlation of the strategic HR involvement and HR devolvement constructs (see Table 2the bolded diagonal elements), indicating an acceptable level of discriminant validity (Fornell and Larcker, 1981).

\section{Common Method Variance}

Data collected from a single respondent may be subject to potential common method bias (Gardner \& Wright, 2009), which may lead to the estimates of the relationship between the predictors and outcome variable to be inflated or deflated. A set of steps were undertaken to reduce the potential for common method variance. Podsakoff and Organ (1986) argue that minimising common method variance (CMV) can be achieved using a method known as 'scale reordering' which requires that items related to the independent variables are placed before items measuring the outcome variable. In our measurement instrument, strategic HR involvement and HR devolvement questions are found earlier, whilst the performance questions are found in the last section. Further, we also attempted to minimise CMV by asking the HR directors in the targeted companies to fill the survey on the basis of required expertise, as prior work suggested that the most senior HR person is well placed to provide information on HR policies and practices (see Guthrie, 2001; Way et al., 2010). To further reduce the potential of common method variance, the Harman's one-factor test was also used post hoc to assess whether or not common method variance is a serious concern (Podsakoff 
and Organ, 1986). Accordingly, principal components factor analysis was conducted for all variables; if a single or one general factor emerges and accounts for the majority of the total variance, this indicates a substantial amount of CMV (Steensma et al., 2005). As a result, principal component analysis with varimax rotation revealed the presence of four distinct factors with eigenvalue greater than 1.0, rather than a single factor. These factors accounted for $61 \%$ of the total variance. Markedly, the first factor (23\%) did not account for a majority of the variance which explains why no single or general factor is apparent. The results suggest that CMV is not of serious concern and hence is unlikely to confound the interpretations of results (Podsakoff and Organ, 1986).

\section{TABLE-1 ABOUT HERE}

\section{Results}

\section{Descriptive Statistics}

Table 2 provides the results of descriptive statistics. It is important to note, at the very outset, that the relationship between strategic HR involvement and HR devolvement is significant. In addition, strategic HR involvement and devolvement are negatively related to employee turnover rate and positively to perceived financial performance.

\section{TABLE-2 ABOUT HERE}


Table 3 reports the results of multiple regression for the first hypothesis. We have tested the impacts of strategic HR involvement and HR devolvement on employee turnover rate for oil and gas and non-oil and gas sectors. As recorded in Table 3, $\mathrm{R}^{2}$ for the first model (oil and gas) is not significant $\left(\mathrm{R}^{2}=.17, \mathrm{p}>.10\right)$, indicating that the predictors account for $17 \%$ of the variation in employee turnover rate. Looking at the individual contributions of the main predictors, the results indicate that strategic HR involvement has only a partial negative impact on employee turnover rate, while HR devolvement was not significant at all. Regarding the second model (non-oil and gas sectors), $\mathrm{R}^{2}$ is significant $\left(\mathrm{R}^{2}=.23, \mathrm{p}<.001\right)$, indicating that the predictors account for $23 \%$ of the variation in employee turnover rate. Looking at the individual contributions of the main predictors, the results indicate that strategic HR involvement has a strong and significant negative impact on employee turnover rate $(b=-.486, t=-6.249, p<.001)$; however, HR devolvement was not significant in its relationship with the outcome variable $(b=-.030, t=-.391, p>.10)$. In summary, the results indicate that strategic HR involvement had a much stronger impact on employee turnover rate in the non-oil and gas sectors than the oil and gas sector; HR devolvement, on the other hand, had no contributions in its relation with employee turnover rate in both sectors. We discuss these findings further in the discussion section.

\section{TABLE-3 ABOUT HERE}


Hypothesis 2: Perceived financial performance regressions for oil and gas and non-oil and gas sectors

Table 4 presents the results of multiple regressions for the second hypothesis. The results indicated that both models are significant with p-values of (0.021) for oil and gas, and (0.000) for other sectors. Notably, the determination coefficient of oil and gas sector model is higher than the non-oil and gas sectors and significantly explains $44.6 \%$ of the variation in perceived financial performance. Looking at the individual contributions of the main predictors, the results indicate that strategic HR involvement is significantly associated with perceived organisational performance in both models (oil and gas: $b=.928, t=3.347, p<.01$ ); (non-oil and gas: $b=.354, t=4.425, p<.001)$. HR devolvement, on the other hand, was only significant in the non-oil and gas sector $(b=.194, t=2.418, p<.05)$. In summary, it generally seems that the alignment between HRM and organisational strategy would enhance the financial returns of the companies. Such findings indicate the importance of involving HR Directors in the strategic affairs of the company, and also empowering Line Managers with greater responsibility in terms of day-to-day HR affairs in generating better financial returns for the companies. More specifically, the results indicate that strategic HR involvement is an important organisational practice and positively and significantly linked with performance regardless of the sector being oil and gas or not; however, the results also indicate that HR devolvement was only significant in non-oil and gas sectors as the latter had no contributions to organisational performance in oil and gas sector.

\section{TABLE-4 ABOUT HERE}


Testing the first and second hypotheses contributes to our understanding of the impact of strategic HR involvement and devolvement on employee turnover and financial performance in oil and gas and non-oil and gas sectors. In order to have additional understanding if there exist any significant differences in SHRI and SHRD practices between the two groups, we extended the analysis further by demarcating the sample into two halves and conducted the Mann-Whitney test which is a non-parametric equivalent of the independent t-test (Field, 2009). Results presented in Table 5 show significant statistical differences between oil and gas and non-oil and gas sectors in terms of involving HR directors in the strategic matters of the organisations $(\mathrm{U}=442.000, \mathrm{z}=-4.126, \mathrm{p}<0.001)$. In other words, oil and gas sector placed much more emphasis in involving HR directors in the overall strategic process of their companies. However, regarding HR devolvement, no significant statistical differences were encountered between the two groups $(U=873.500, Z=-1.598, p>0.05)$. As a result, the third hypothesis is only partially proved. We discuss these results in the next section

\section{TABLE-5 ABOUT HERE}

\section{Discussion and Conclusions}

Our findings highlighted significant sectoral variations in terms of the performance consequences of how HR management is organized. We found that strategic HR involvement made a real difference in reducing employee turnover in the non-oil and gas sector. Within the oil and gas sector, these differences were not encountered; this would reflect the structural 
dynamics of the sector itself, with employment being much more desirable than other areas (outside of the public sector), but with endemic poaching of highly skilled local staff to meet indigenization quotas. In many petrostates, relatively privileged "insider" grouping of indigenous nationals regularly engage in job hopping and/or shunning challenging employment for more sheltered positions in the state, whilst the most productive and talented individuals seek to move to lucrative positions in the oil and gas sector unless firms in other areas proactively implement measures to retain them (c.f. Mellahi 2007; Mellahi and Wood 2002). At the same time, this does show that firm level HR interventions can make a real difference in mitigating some of the challenges in non-resource sectors. However, HR devolvement had no effect on turnover across the economy. This would reflect the extent to which devolvement might represent very different realities - either the delegation of routine functions to allow HR managers to concentrate on strategic issues, or simply the lack of a fully developed HR function. Hence, the first may be to shift a great deal of everyday administration to frontline HR management, once more allowing the HR department to focus on broader strategic matters. The second may reflect a near absence of an HR function, with basic HR administration being performed at the frontline, but with little in the way of broader HR capabilities.

However, whilst a feature of most petrostates is a highly segmented labour market that firm level HR managers have, at best to cope with, this does not mean that the involvement of HR managers in setting strategy had no impact whatsoever. Rather, it appears to have had a beneficial effect on overall performance. However, HR devolvement did appear to have significantly positive performance consequences for firms only in non-resource industries. Again, this could reflect the ambiguity of HR devolvement. Many firms in the non-oil and 
gas industry remain locked in a basic cost cutting mode, and, in such circumstances, fully developed central managerial bureaucratic functions may be simply financially unsustainable.

Yet, even if strategic HR may be more important in non-resource sectors (as firms in the oil and gas industry tended to do better regardless of their HR strategies), it appears more difficult to implement. In other words, not only was strategic HRM more important, but it also appeared less common in non-oil and gas industries. This could reflect the greater resources available to firms in the oil and gas industry when compared to other private sector players, enabling them to hire the best HR managers and invest more in developing HR processes and procedures. Again, working in oil and gas could be more prestigious and rewarding, making it easier to attract high quality rank-and-file staff.

In summary, we encountered sectoral divergence when it came to strategic HR involvement in central issues of organizational strategy, and ostensibly similar practices when it came to devolvement; however, the former is likely to mould the latter, with devolvement either reflecting a concentration of the HR department on strategic issues, or a simple lack of capability and resources on behalf of the latter. However, in many petrostates with large foreign labour forces performing semi and unskilled job roles, HR devolvement may also reflect less than benign systemic features irrespective of sector. Such foreign workers (be they in Brunei or the Gulf) generally have very few rights under the law; it may be the case that an appetite for devolvement of HR in such settings may also reflect a desire to abrogate responsibility for the low value added 'dirty work' of implementing repressive forms of work and employment relations onto low level supervisors and foremen.

This, in turn, raises some important questions for HR practice. Firstly, there is the potential role of HR managers as potential 'norm entrepreneurs', promoting higher value added and 
more ethical HR practices in challenging circumstances. The study revealed the relative empowerment of HR managers is closely bound up with sectorial dynamics; hence, such 'norm entrepreneurship' would be likely to reinforce existing internal diversity, rather than help bridge the gap in practice between oil and gas, and other sectors. Secondly, the study highlights the extent to which long historical legacies - and disadvantages - both within and across national institutional contexts may be difficult to overcome, with the viability of both strategic approaches to HRM and HPWS being closely dependent on circumstances (c.f. Brewster et al., 2007). This does not mean that there remains considerable room for innovation at firm level, or the possibility for fresh strategic initiatives, but rather that the range of choices and likely outcomes will be constrained or enabled by circumstances.

Brunei has attracted a large amount of foreign investments during recent times, primarily on the back of oil and gas; yet, within many petro-states non-oil and -gas sectors have faced serious challenges in securing sustainable competitiveness. Our findings highlight the need for HR Directors in Brunei — as well as in comparable settings - to assume a broader role beyond the technicalities of day-to-day HRM. Conservative Line Managers may follow embedded local prejudices against the less skilled categories of 'guest' workers, making their greater involvement in HR issues counter-productive (c.f. Santosa, 2009). Again, if firms operating in the non-oil and gas industries in petrostates face intrinsic challenges of competitiveness, HRM may not only be more important, but also under-resourced. In such circumstances, organizations may operate on a low-level survival mode, and be reluctant to invest on areas beyond immediate operations. Such trends may be manifested in other petrostates for similar 'resource curse' reasons; indeed, evidence from Saudi Arabia suggests that firms outside the oil and gas industry faced severe HR challenges in skills and resourcing, and, more broadly speaking, in finding a sustainable base of competitiveness (Mellahi 2002; Mellahi and Wood 2002; Budhwar and Mellahi 2006). A fertile area for 
future research would be to compile comparable research evidence from other such countries. The latter could facilitate in developing a specific archetype of HR practice in petrostates, and in identifying what features of practice are unique to Brunei alone.

Finally, we acknowledge some limitations of the present work. We employ a cross-sectional design, which does not allow researchers to rule out the possibility of reverse causation (Wright et al., 2001). A longitudinal design would help to strengthen the reverse causation possibility and, as a result, to overcome the time-lag effects of HRM on performance (Andersen et al., 2007). Moreover, the data related to strategic HR involvement, HR devolvement and OP was collected from single respondents. Although cross-checks revealed data to be consistent, some elements of common method variance bias may have crept in. Time and funds permitting, future researchers can endeavour to use multiple respondents to gather HRM data. Finally, a closer examination between the relative efficacy of HR devolvement and workforce composition in contexts such as Brunei might yield some interesting new insights into the challenges associated with managing different categories of expatriate.

This research is based on single country case study, but echoes and extends earlier work on HR in petrostates (c.f. Mellahi 2007). A fertile ground for future research would be to broaden the panel of petrostate country cases; it is possible that in petrostates with more developed institutions and corporate governance structures, the segmentation may be less pronounced, reflecting more mature training and skills development capabilities, and more even handed treatment of firms across the national economy (c.f. Mehlum et al 2006).

Whilst the resource curse literature suggests that firms in non-oil and gas industries in petrostates face structurally induced difficulties, we found that some of the negative HR 
consequences could be ameliorated through strategic choice, and in particular, in how firms manage their people. What our study confirms is that people management can make a real difference even in marginalized areas of national economies. However, whilst firms in the latter area are less likely to have the capabilities or resources to develop a strategic HRM function, developing and enhancing the role of people management is still very much easier than bringing about structural institutional reforms: in the end, at least part of the solution to contextual difficulties lies within.

\section{References}

Alexeev, M. and Conrad, R. (2009). The elusive curse of oil, The Review of Economics and Statistics, 91(3): 586-598.

Andersen, J. and Ross, M. (2015). The big oil change: A Closer Look at the Haber-Menaldo Analysis, Comparative Political Studies, doi 0010414013488557. Early online at: http://cps.sagepub.com/content/early/2013/06/13/0010414013488557.abstract

Andersen, K., Cooper, B. and Zhu, C. (2007). The effect of SHRM practices on perceived firm financial performance: Some initial evidence from Australia. Asia Pacific Journal of Human Resources,45: 168-179.

Arthur, J. B. (1994). Effects of human resource systems on manufacturing performance and turnover. Academy of Management Journal, 37: 670-687.

Auty, R. (1993). Sustaining Development in Mineral Economies: The Resource Curse Thesis. Routledge: London.

Bae, J. and Lawler, J.J. (2000). Organizational and HRM strategies in Korea: Impact on firm performance in an emerging economy. Academy of Management Journal, 43: 502-517.

Becker, B.E., \& Huselid, M.A. (1998). High performance works systems and firm performance: A synthesis of research and managerial implications. In K.M. Rowland \& G.R.Ferris (Eds.), Research in personnel and human resource management, 16: 53-101. Greenwich, CT: JAI.

Bhattacharya, S. and Hodler, R. (2010). Natural Resources, democracy, and corruption. European Economic Review, 54: 608-621.

Bowen, D. E., \& Ostroff, C. (2004). Understanding HRM-firm performance linkages: The role of the "strength" of the HRM system, Academy of management review, 29: 203-221. 
Brewster, C., Wood, G., Croucher, R. and Brookes, M. (2007). Collective and Individual Voice: Convergence in Europe? International Journal of Human Resource Management, 18, 7: 1246-1262.

Brewster, C. and Larsen, H. H. (1992). Human resource management in Europe: Evidence from ten countries. International Journal of Human Resource Management, 3: 409-433.

Budhwar, P. (2000). Evaluating levels of strategic integration and devolvement of human resource management in the UK. Personnel Review, 29: 141-161.

Budhwar, P. and Khatri, N. (2001). HRM in context: Applicability of HRM models in India. International Journal of Cross Cultural Management, 1: 333-356.

Budhwar, P. and Sparrow, P. R. (1997). Evaluating levels of strategic integration and devolvement of human resource management in India. International Journal of Human Resource Management, 8: 476-94.

Budhwar, P. S., \& Mellahi, K. (2006). Managing Human Resources in the Middle-East. Routledge: London.

Central Intelligence Agency (2016). The World Factbook reports, accessed at: https://www.cia.gov/library/publications/the-world-factbook/fields/2112.html.

Chand, M. and Katou, A. (2007). The impact of HRM practices on organisational performance in the Indian hotel industry. Employee Relations, 29: 576-594.

Chang, W. and Huang, T. (2005). Relationship between strategic human resource management and firm performance: A contingency approach. International Journal of Manpower, 26: 434-449.

Collier, P. (2010). The political economy of natural resources. Social Research, 77(4): 11051132.

Cunningham, I. and Hyman, J. (1999). Devolving human resource responsibilities to the line: Beginning of the end or a new beginning for personnel? Personnel Review, 28: 9-27.

Darwish, T. and Singh, S. (2013). Does strategic HR involvement and devolvement enhance organisational performance? Evidence from Jordan. International Journal of Manpower, 34: 674-692.

Darwish, T., Singh, S. and Mohamed, A. F. (2013). The role of strategic HR practices in organisational effectiveness: An investigation in the country of Jordan. International Journal of Human Resource Management, 24: 3343-3362.

Darwish, T., Singh, S. and Wood, G. (2015). The impact of human resource practices on actual and perceived organizational performance in a Middle-Eastern emerging market. Human Resource Management. DOI: 10.1002/hrm.21664. 
Delaney, J. T. and Huselid, M. A. (1996). The impact of human resource management practices on perceptions of organizational performance. Academy of Management Journal, 39: 949-969.

Delery, J. E. and Doty, D. H. (1996). Modes of theorizing in strategic human resource management: Tests of universalistic, contingency. Academy of Management Journal, 39: $802-835$.

Dess, G.G., and Robinson, R.B. (1984). Measuring organizational performance in the absence of objective measures: The case of the privately-held firm and conglomerate business unit. Strategic Management Journal, 5: 265-279.

Dyer, L. and Reeves, T. (1995). Human resource strategies and firm performance: What do we know and where do we need to go? International Journal of Human Resource Management, 6: 656-670.

Evans, W. R., \& Davis, W. D. (2005). High-performance work systems and organizational performance: The mediating role of internal social structure. Journal of Management, 31: 758-775.

Field, A. (2009). Discovering Statistics Using SPSS, Sage: London.

Fornell, C. and Larcker, D. (1981). Evaluating structural equation models with unobservable variables and measurement error. Journal of Marketing Research, 18: 39-50.

Gardner, T. M., and Wright, P. M. (2009). Implicit human resource management theory: A potential threat to the internal validity of human resource practice measures. The International Journal of Human Resource Management, 20: 57-74.

Geringer, M. J. and Hebert, L. (1991). Measuring performance of international joint ventures. Journal of International Business Studies, 28: 249-263.

Guest, D. E. (1997). Human resource management and performance: A review and research agenda. International Journal of Human Resource Management, 8: 263-276.

Guest, D. E. (2011). Human resource management and performance: Still searching for some answers. Human Resource Management Journal, 22: 3 - 13.

Guthrie, J. P. (2001). High-involvement work practices, turnover, and productivity: Evidence from New Zealand. Academy of management Journal, 44: 180-190.

Guthrie, J. P, Flood, P., Liu, W. and MacCurtain, S. (2009). High performance work system in Ireland: Human resource and organisational outcomes. The International Journal of Human Resource Management, 20: 112-125. 
Haber, S. and Menaldo, V. (2001). Do natural resources fuel authoritarianism? A reappraisal of the resource curse, American Political Science Review, 105(01):1-26.

Hair, J. F., Black, W. C., Babin, B. J. and Anderson, R. E. (201). Multivariate Data Analysis, Upper Saddle River: Prentice Hall, NJ.

Holt, D. (1993). Management Principles and Practices, Englewood Cliff: Prentice Hall, NJ.

Huang, T. C. (2000). Are the human resource practices of effective firms distinctly different from those of poorly performing ones? Evidence from Taiwanese enterprises, International Journal of Human Resource Management, 11: 436-451.

Huselid, M. (1995). The impact of human resource management practices on turnover, productivity, and corporate financial performance. Academy of Management Journal, 38: 635-670.

Joseph, K. E. and Dai, C. (2009). HRM practices and organizational performance: An empirical analysis. International Journal of Business and Management, 4: 117-127.

Karami, A., Jones, B. and Kakabadse, N. (2008). Does strategic human resource management matter in high-tech sector? Some learning points for SME managers. Corporate Governance, 8: $7-17$.

Khatri, N. (1999). Emerging issues in strategic HRM in Singapore. International Journal of Manpower, 20: 51-52.

Lawler,E.E. (1992). The ultimate advantage: Creating the high involvement organization. San Francisco: Jossey-Bass.

Lawrey, R. N. (2010). An economist's perspective on economic diversification in Brunei Darussalam. CSPS Strategy and Policy Journal, 1: 13-28.

MacDuffie, J. P. (1995). Human resource bundles on manufacturing performance: Organizational logic and flexible production systems in the world auto industry. Industrial and Labour Relations Review, 48: 197-221.

Macky, K., and Boxall, P. (2007). The relationship between 'high-performance work practices' and employee attitudes: An investigation of additive and interaction effects. International Journal of Human Resource Management, 18: 537 -567.

Mellahi, K., \& Wood, G. (2002). Desperately seeking stability: the making and remaking of the Saudi Arabian petroleum growth regime. Competition and Change, 6(4): 345-62.

Mellahi, K. (2007). The effect of regulations on HRM: private sector firms in Saudi Arabia. The International Journal of Human Resource Management, 18(1): 85-99. 
Mehlum, H., Moene, K., \&Torvik, R. (2006). Institutions and the resource curse, The Economic Journal, 116(508): 1-20.

Minnis, J. R. (2000). Caught between Tradition and Modernity: Technical and Vocational Education in Brunei Darussalam. Journal of Educational Development, 20: 247-259.

Moideenkutty, U., Al-Lamki, A. and Murthy, Y. (2011). HRM practices and organisational performance in Oman. Personnel Review, 40: 239- 251.

Moser, C. A. and Kalton, G. (1985). Survey Methods in Social Investigation, Gower: Aldershot.

Nunnally, J. C. (1967). Psychometric Theory. McGraw-Hill, NY.

Nuur, C. and Laestadius, S. (2010). Natural resources and old industrialized nations: is there a regional dimension to the resource curse? In The 8th conference of the EURS conference.

Othman, A. (2009). Strategic integration of human resource management practices. Cross Cultural Management, 16: 197-214.

Paauwe, J. (2009). HRM and performance: Achievements, methodological, issues and prospects. Journal of Management Studies, 46: 129-142.

Paauwe, J. and Boselie, P. (2005). HRM and performance: What next? Human Resource Management Journal, 15: 68-83.

Pfeffer, J. (1998). Seven practices of successful organizations. California Management Review, 40: 96-124.

Podsakoff. P. M. and Organ, D. W. (1986). Self-reports in organizational research: problems and prospects. Journal of Management, 12: 531-544.

Powell, T. C. (1992). Organisational alignment as a competitive advantage. Strategic Management Journal, 13: 119-134.

Razouk, A. (2011). High performance work systems and performance of French small- and medium-sized enterprises: Examining causal order. International Journal of Human Resource Management, 22: 311-330.

Rogers, E. and Wright, P. (1998). Measuring organisational performance in strategic human resource management: Problems, prospects, and performance information markets. Human Resource Management Review, 8: 311-331.

Ross, M. (2012). The oil curse: how petroleum wealth shapes the development of nations. Princeton: Princeton University Press. 
Santoso, D. (2009). The construction site as a multicultural workplace: a perspective of minority migrant workers in Brunei. Construction Management and Economics, 29: 529-537.

Sheehan, M. (2012). Devolvement of HRM and perceived performance within multinational corporations (MNCs). European Journal of International Management, 6: 101-127.

Singh S, Darwish T, and Anderson N. (2012a). Strategic intent, high performance HRM, and the role of the HR director: An investigation into attitudes and practices in the country of Jordan. International Journal of Human Resource Management, 23: 3027-3044.

Singh, S., Darwish, T., Costa, A.C. and Anderson, N. (2012b). Measuring HRM and organisational performance: Concepts, issues, and framework. Management Decision, 50: 651-667.

Singh, S., Darwish, T. K., \& Potočnik, K. (2016). Measuring Organizational Performance: A Case for Subjective Measures. British Journal of Management. DOI: 10.1111/14678551.12126.

Steensma, H.K., Tihanyi, L., Lyles, M.A., \& Dhanaraj, C. (2005). The evolving value of foreign partnerships in transitioning economies. Academy of Management Journal, 48: 213-235.

Sullivan, J. (2003). Knocking down the silos. Human Resource. March: 16-18.

Tasie, G. (2009), 'Can Japanese management styles be applied to Africa? African Journal of Business Management, 3: 233-239.

The Economic Outlook for Southeast Asia, China and India (2014): Beyond the MiddleIncome Trap, http://dx.doi.org/10.1787/saeo-2014-en.

Truss, C. and Gratton, L. (1994). Strategic human resource management: A conceptual approach. International Journal of Human Resource Management, 5: 663-686.

Truss, C., Gratton, L., Hope-Hailey, V., Mcgovern, P. and Stiles, P. (1997). Soft and hard models of human resource management: A reappraisal. Journal of Management Studies, 34: 53-73.

Tzafrir, S. (2005). The relationship between trust, HRM, and firm performances. International Journal of Human Resource Management, 16: 1600-1622.

Wall, T. D., Michie, J., Patterson, M., Wood, S., Sheehan, M., Clegg, C. W. and West, M. (2004). On the validity of subjective measures of company performance. Personnel Psychology, 57: 95-118.

Way, S. (2002). High performance work systems and intermediate indicators of firm performance within the US small business sector. Journal of Management, 28: 765-785. 
Way, S. A., Lepak, D. P., Fay, C. H., \& Thacker, J. W. (2010). Contingent workers' impact on standard employee withdrawal behaviors: does what you use them for matter? Human Resource Management, 49: 109-138.

Wiens, D., Poast, P. and Williams, C. (2015). The political resource curse: an empirical reevaluation, Political Research Quarterly, doi: 1065912914543836. Early online at http://prq.sagepub.com/content/early/2014/07/25/1065912914543836.abstract

Wood, G., Dibben, P. and Ogden, S. (2014). Comparative Capitalism without Capitalism, and Production without Workers: The Limits and Possibilities of Contemporary Institutional Analysis. International Journal of Management Reviews, 16, 4: 384-396.

Wright, P. M., Dunford, B.B. and Scott, S. (2001). Human resources and the resource based view of the firm. Journal of Management, 27: 701-721.

Wright, P. M., Gardner, T. M., Moynihan, L. M. Allen, M. R. (2005). The relationship between HR practices and firm performance: Examining causal order. Personnel Psychology, 58: $409-446$.

Wright, P.M., McCormick, B., Sherman, W.S. and McMahan, G.C. (1999). The role of human resource practices in petro-chemical refinery performance. International Journal of Human Resource Management, 10: 551-571. 
Table 1: Convergent validity-standardised factor loadings, AVE, and reliability results

\begin{tabular}{|c|c|c|c|}
\hline Items & $\begin{array}{l}\text { Strategic HR } \\
\text { Involvement }\end{array}$ & HR Devolvement & $\begin{array}{l}\text { Perceived } \\
\text { Financial } \\
\text { Performance }\end{array}$ \\
\hline $\begin{array}{l}\text { The HR director has become more in } \\
\text { decision making process. }\end{array}$ & .842 & & \\
\hline $\begin{array}{l}\text { The level of the representation of the } \\
\text { of Board meeting. }\end{array}$ & .744 & & \\
\hline $\begin{array}{l}\text { Contribute to planning and impleme } \\
\text { corporate strategies. }\end{array}$ & .698 & & \\
\hline Advising on organisational design. & 671 & & \\
\hline $\begin{array}{l}\text { How important is the delegation of } t \\
\text { work to Line Managers. }\end{array}$ & & .778 & \\
\hline $\begin{array}{l}\text { How important is the delegation of } \mathrm{t} \\
\text { decisions to Line Managers*. }\end{array}$ & & .771 & \\
\hline Sales revenue & & & .952 \\
\hline Profitability (after tax) & & & .935 \\
\hline Holding market share & & & .870 \\
\hline Average Variance Extracted (AVE) & .55 & .60 & .84 \\
\hline Cronbach's $\alpha$ & .75 & .69 & .90 \\
\hline
\end{tabular}

*Reverse question. 
Table 2: Mean, standard deviations, discriminant validity, and correlations for all variables

\begin{tabular}{llllllll}
\hline & \multicolumn{1}{c}{ Variables } & Mean & S.D. & 1 & 2 & 3 & 4 \\
\hline 1. & Strategic HR Involvement & 3.71 & 0.74 & .74 & & & \\
2. & HR Devolvement & 3.17 & 0.80 & $.42^{* *}$ & .77 & & \\
3. & Employee Turnover & 2.46 & 1.88 & $-.48^{* *}$ & $-.30^{* *}$ & -- & \\
4. & Perceived Financial Performance & 6.98 & 1.69 & $.44^{* *}$ & $.33^{* *}$ & $-.27^{* *}$ & -- \\
& & & & & & & \\
\hline
\end{tabular}

Notes: $\quad n=151 . * *$ Correlation is significant at the 0.01 level (two-tailed); * Correlation is significant at the 0.05 level (two-tailed)

Bold diagonal elements are square roots of average variance extracted. 
Table 3: Employee turnover rate regressions for oil and gas and non-oil and gas sectors

\begin{tabular}{|l|r|r|r|r|r|r|}
\hline Variables & \multicolumn{3}{|c|}{ Oil and gas sector } & \multicolumn{3}{c|}{ Non-oil and gas sectors } \\
\hline & $\begin{array}{l}\text { Standardized } \\
\text { coefficient }\end{array}$ & $\mathrm{t}$ & P-value & $\begin{array}{l}\text { Standardized } \\
\text { Coefficient }\end{array}$ & $\mathrm{T}$ & P-value \\
\hline Strategic HR Involvement & -.644 & -1.901 & .086 & -.486 & -6.249 & .000 \\
\hline HR Devolvement & .158 & .467 & .651 & -.030 & -.391 & .696 \\
\hline
\end{tabular}

\begin{tabular}{|l|c|c|}
\hline $\mathrm{F}(\mathrm{p}$-Value $)$ & $2.257(0.155)$ & $22.0(0.000)$ \\
\hline $\mathrm{R}^{2}$ & .173 & .235 \\
\hline
\end{tabular}

Table 4: Perceived financial performance regressions for oil and gas and non-oil and gas sectors

\begin{tabular}{|l|r|l|r|r|l|r|}
\hline Variables & \multicolumn{3}{|c|}{ Oil and gas sector } & \multicolumn{3}{c|}{ Non-oil and gas sectors } \\
\hline & $\begin{array}{l}\text { Standardized } \\
\text { coefficient }\end{array}$ & $\mathrm{t}$ & P-value & $\begin{array}{l}\text { Standardized } \\
\text { coefficient }\end{array}$ & $\mathrm{T}$ & P-value \\
\hline Strategic HR Involvement & .928 & 3.347 & .007 & .354 & 4.425 & .000 \\
\hline HR Devolvement & -.441 & -1.591 & .143 & .194 & 2.418 & .017 \\
\hline
\end{tabular}

\begin{tabular}{|l|c|c|}
\hline F (p-Value) & $5.830(0.021)$ & $17.037(0.000)$ \\
\hline $\mathrm{R}^{2}$ & .446 & .190 \\
\hline
\end{tabular}

Table 5: A comparative analysis between oil and gas and non-oil and gas sectors

\begin{tabular}{|l|l|r|r|r|r|}
\hline & Sector & Mean Rank & Mann-Whitney U & Z-statistics & Sig. \\
\hline Strategic HR & Non-oil and gas & 70.80 & 442.000 & -4.126 & .000 \\
Involvement & Oil and gas & 117.00 & & & \\
\hline \multirow{2}{*}{ HR Devolvement } & Non-oil and gas & 74.02 & 873.500 & -1.598 & .110 \\
& Oil and gas & 91.62 & & & \\
\hline
\end{tabular}

*Significant at the 0.05 level 